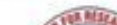 seconosont READS Review of Economics and Development Studies \\ Journal homepage: http://reads.spcrd.org \\ ISSN (Print): 2519-9692 \\ ISSN (Online): 2519-9706
}

\section{War against Terror Impacts on Pakistan's Economy: A Critical Discourse Analysis of Pakistani Newspapers}

${ }^{a}$ Sarwat jabeen, ${ }^{b}$ Tazanfal Tehseem, ${ }^{c}$ Samia Naz

${ }^{a}$ Assistant professor, Department of English, Bahauddin Zakariya university multan, Pakistan

${ }^{\mathrm{b}}$ Lecturer, department of English, University of Sargodha, Punjab, Pakistan

${ }^{\mathrm{c}}$ Course coordinator at Quaid-e- Azam Academy for educational development Lahore, Punjab pakistan

ARTICLE DETAILS
History:
Accepted o4 May 2020
Available Online 15 June 2020

\section{Keywords:}

Critical Discourse Analysis,

Newspaper, Political Cartoon, Ideology, War On Terror,

Pakistan's Economy

JEL Classification:

L86, C61, C69

DOI: $10.47067 /$ reads.v6i2.229

\begin{abstract}
The present research is an attempt to explore the discourses of political cartoons published in Pakistani Urdu and English newspapers representing the war against terror impacts on Pakistan's economy. Newspapers' linguistic and semiotic representations of war against terror impacts on Pakistan's economy are ideologically loaded and employed in the construction and deconstruction of the realities of post 9/11 scenario in a desired way. The research uses multimodal critical discourse approach (Machin, 2007) along with Van Leeuwen's framework for recontextualisation (2008) and Fairclough's (2003) framework for visual and linguistic analyses of the political cartoons to explore the hidden ideologies. The visual and linguistic analyses of the political cartoons pay careful attention to how discourses are chosen and then represented visually and linguistically to promote particular interests and ideologies that shape public perception of the reality.
\end{abstract}

(C) 2020 The authors. Published by SPCRD Global Publishing. This is an open access article under the Creative Commons Attribution-

NonCommercial 4.0

Corresponding author's email address: sarwat.awan4@gmail.com

\section{Introduction}

The tragic events of September11, 2001, were shocking abrupt and horrifyingly dramatic had great impacts on the whole world. The consequence of this surprise was greater global activism by the US. It led the US to form a global coalition against the menace of international terrorism. The 9/11 tremors were felt throughout the world but nowhere more strongly than in Pakistan. Pakistan's role as a frontline state in the war against terror has exposed it to much graver crises. The post 9/11 events got extensive coverage in Pakistani Urdu and English newspapers. The research paper investigates the ideological representations of Pakistan's economic condition in political cartoons with reference to Pakistani English and Urdu newspapers in the post 9/11 scenario. The analysis raises an awareness of the broader context within which the economic condition of Pakistan is constructed and represented in political cartoons. The discourse of political cartoons includes representations of participants, settings, poses and objects along with linguistic captions. This analysis allows us to see how political cartoons represent and recontextualise the developments took place after Pakistan's participation in war against 
terror.

\section{Literature Review}

Media is the primary crucible for representation in the world today. It is an arena where ideologies are both produced and transformed. A critical perspective is instrumental to examine how media articulates the dominant values and the socio political ideologies in a society. Such examination is vital to understand how groups exercise their power to maintain their ideologies. Ideology being the system of beliefs organizes the way in which we view the world and the events that take place in it. Ideologies are proposition that generally figure as implicit assumptions in texts, which contribute to producing or reproducing unequal relations of domination (Fairclough, 1995). He further says that discourse is "a particular way of constructing a particular (domain of) social practice" (1995: 76). The analysis of any type of discourse helps us understand the use of language in context as meanings are embedded in their contextual use. Critical discourse analysis systematically considers the issue of control, power and dominance in the production of texts and pays attention to gaining of knowledge how this shapes discourse (Van Dijk, 2001). The study draws upon CDA and MCDA for depicting, interpreting and analyzing the ideological discourses of Pakistani leading English and Urdu newspapers. Weiss and Wodak (2003) remind the reader the underlying premise of CDA which is that discourse shapes social events and is shaped by them. CDA of the political cartoons in the present study discloses the explicit and implicit meanings used ideologically in these cartoons to shape the perception of the people. Multimodal critical discourse analysis shows how images, graphs, diagrams, and photographs work to create meanings. Choices are made by the authors to communicate the idea in desired ways. By using the tools carefully within this framework, we can identify these choices as described by Machin and Mayr 'texts will use linguistics and visual strategies that appear normal or neutral on the surface, but which may in fact be ideological and seek to shape the representation of events and persons for particular ends' (2012: 9). The insights which the MCDA brings to the critical reader can assist in understanding how ideology operates through language deployed for particular ends by powerful groups in society.

\section{3-Methodology}

The present research aims at decoding the linguistic and semiotics discourses of political cartoons published in the Pakistani Urdu (Ausaf, Jang) and English (Dawn, The Nation) newspapers. At the time of data collection, political cartoons were published daily in these newspapers. The researcher has collected data from following Pakistani English and Urdu newspapers:

- English Newspapers:

Dawn (English, daily)

The Nation (English, daily)

- Urdu Newspapers:

Jang (Urdu, daily)

Ausaf (Urdu, daily)

These newspapers selected on the basis of following criteria:

1. wide circulation of these newspapers

2. maximum readership

3. old and well-reputed

4. daily newspapers 
Review of Economics and Development Studies, Vol. 6 (2) 2020, 531-543

5. publish political cartoon daily

- Dawn

It is Pakistan's oldest and internationally best acknowledged English newspapers. It was founded by Quaid-Azam Muhammad Ali Jinnah before the formation of Pakistan on 26 October 1941.

- The Nation

The nation is another largest and oldest English-language daily newspaper in Pakistan. It was founded in 1986.

- Jang

Jang is the oldest Urdu newspaper in Pakistan in continuous publication since its foundation in 1939. It is very well reputed and widely circulated.

- Ausaf

Daily Ausaf was inaugurated in Islamabad on 25 December 1997. It is daily Urdu newspaper which is being published simultaneously from different cities of Pakistan and from London and Frankfurt. It is one of the leading Urdu newspapers in Pakistan.

\subsection{Selection of Data for Analysis}

The researcher has selected political cartoons from the above mentioned newspapers appearing during 10 September 2001 to 31 December 2001. It is important to note that political activity was at its peak when political cartoons were extracted prior to US attack on Afghanistan.

\subsection{Reasons for the Selection of Urdu/ English Newspapers}

Urdu and English newspapers are selected in order to see their representations of post 9/11 scenario. Urdu newspapers are generally considered the representatives of the common people of Pakistan. These are published in Urdu language so a common person with less education can read the Urdu newspapers easily. Urdu newspapers represent the maximum readership because in Pakistan readers of Urdu newspapers are more than those of English newspapers. English newspapers are read by elites or highly educated people who understand English language well. These are also considered pro-western in policies. Urdu and English newspapers are selected to see the differences in ideological representation of post 9/11 scenario. How both types of newspapers represent ideology regarding the issue as their readership differs.

\subsection{Research Questions}

- What key themes recur in the political cartoons published in the selected newspapers on the issue of economy?

- How do the political cartoons characterize the figures, their actions and the themes that make up the message of war on terror's impact on Pakistan's economy?

- What ideologies underlay these themes and how are they legitimized?

- Is there any ideological similarity or difference represented in Urdu/English political cartoons over the issue?

\subsection{Framework for the Present Study}

In order to explore the research questions, multimodal critical discourse analysis is used to analyse the data. The researcher follows multimodal critical discourse approach (Machin, 2007) along with Van Leeuwen's framework for recontextualisation (2008) and Fairclough's (2003) framework for visual and linguistic analyses of the political cartoons regarding the ideological representations of war 


\section{Review of Economics and Development Studies, Vol. 6 (2) 2020, 531-543}

on terror in post September 11 scenario. The analysis also draws on Leeuwen's $(1996,2008)$ framework for the representation of social actors, which offers a category of overdetermination to read how participants are presented physically overdetermined in order to communicate particular ideology and also for recontextualisation of social practice. Machin's (2007) multimodal critical discourse modal provides a toolkit to analyse the semiotic resources such as persons, settings, objects and poses. What meanings the particular signs carry? How signs are used in combination to achieve set aims? The purpose is to reveal what kinds of representations are present in political cartoons both explicitly and implicitly. A toolkit for analysis from Machin's (2007) modal for multimodal critical discourse analysis:

\subsubsection{Participants}

Here, the researcher focuses on the depiction of people in visual communication. Also important is what people are depicted as doing. Machin (2007, p. 109-123) says 'analyzing the precise details of actions in written or speech can reveal more subtle messages about the way people are represented as having power or as being passive....applying this to images gives us a more precise tool kit for thinking about action and agency'. It allows us to think about who has agency, who has the ability to act upon the world.

\subsubsection{Settings}

Settings are important carrier of connotations. According to Mcahin (2007) settings are used to connote discourses and their values, identities and actions. Settings, kinds of people and place can each connote whole sequences of activity.

\subsubsection{Poses}

Poses play their part in connoting meaning from particular discourse. 'Poses are a semiotic resource that can be used for their meaning potential. We must pay careful attention to these when we wish to understand what kinds of people are depicted in the image' (Machin, 2007: 31).

\subsubsection{Objects}

Here, we are concerned with the ideas and values communicated by objects and how they are represented. What discourse do they communicate? According to Machin (2007) objects being the important carrier of connotation transport meanings that connote the particular context and work in combination with other semiotic resources to clear the meanings.

The researcher follows (Machin, 2007) framework for all aspects of analysis of social actors except where she inserts Van Leeuwen's (1996) more specific category for the analysis of the overdetermined features of the social actors. We see in the cartoons that the images do not appear natural or real rather they are modified or overdetermined in terms of appearance, look and physique, in order to analyze this We have used Van Leeuwen representation of social actors (1996) includes a category, overdetermination. According to him overdetermination is done in representation to express views that cannot be said straightforwardly because of political or other censorship. Van Leeuwen (1996) refers to the exaggeration of certain features as overdetermination.

My second methodological tool is recontextualisation. The term refers to semiotic resources for indicating as how political cartoons reconstruct discourse from the events that draw on them. We know that discourses are multi-layered and embedded in social practices which they recontextualise. Political cartoons recontextualise the political situations or events took place after 9/11. 'Recontextualisation can exclude some of the participants of the practice they recontextualise' (Leeuwen, 2008: 8). They therefore act in the interest of those who want to disseminate particular 
Review of Economics and Development Studies, Vol. 6 (2) 2020, 531-543

ideologies and viewpoints to seek benefits. In this view, therefore, semiotic resources are vehicle of communication, or even of persuasion, but are mean of social construction (Machin and Abousnnouga, 2010: 29). Leeuwen (2008, p. 12) says 'recontextualisation makes the social practices explicit to a greater or lesser degree; it makes them pass through the filter of the practices in which they are inserted'. We have used these categories of recontextualisation to access the ways the participants and events are characterized in political cartoons which Leeuwen (2008) identified as substitutions, deletions, rearrangement and evaluation.

\section{Discourses of War against Terror Impacts on Pakistan's Economy in Political Cartoons}

The discourses of Pakistan's economic condition emphasize different issues such as war's effects on Pakistan, crumbling economy of Pakistan, American aid, foreign investment in the form of terrorism, local industry in worst slump, rescheduling of Pak-US loan and disappointment of Pakistani leaders, high inflation, sharp fall and crashes in stock exchange, insecure environment for the foreign investors and people's resentment against government decision etc. The settings foreground the adversity and misfortunes of the common people, break downs in the local industry, unfavourable environment for foreign investment and leaders' helplessness in front of the superpowers. These are designed to escalate public anger against the government and projecting the ideologies to challenge the Western and American intervention into local politics.

Political cartoons represent social actors in particular context like Musharraf is always shown begging and beseeching for aid and feature Western representatives giving cold shoulder to him. The objects also bring the sense of humiliation for Pakistani high officials carrying begging bowl and receiving small gift hampers from America in the form of aid. The primary focus and culprit is America and its high officials and this image is intensified through exaggerations and negative portrayal.

\subsection{The Analysis of Visual Representations of War against Terror Impacts on Pakistan's Economy in Political Cartoons}

The analysis of the theme is done to see how the semiotic resources like settings, actions, objects and poses are used and arranged to create and communicate particular meanings and ideologies and how the recontextualisation is taking place. The four selected cartoons address these issues: American aid to Pakistan, cloud of mercy, major economic relief from Bush and condition of Pakistan's economy.

\subsubsection{Participants}

The frequent social actors in these cartoons are the high officials of Pakistan and the US government. Figure 1 contains three participants Pakistani Finance Minister Shoukat Aziz, American Ambassador Wendy J. Chamberlin and a small child representing Pakistan's economy. The participants are involved in material and behavioral processes. It can be seen that Aziz is carrying a small child in his hands and Chamberlin is dropping drops in his mouth. 




Figure 1 taken from daily 'Dawn' Dated: 17-11-2001

The action connotes the injection of Pakistan's economy by the US dollar to improve its health. The smiling faces of both Aziz and Chamberlin suggest their pleasure while performing this act. The child seems very weak and feeble and needs to be properly fed in order to gain good health. Aziz and Chamberlin are wearing formal suits and represented as professionals. Their hair are well styled and combed. This look helps to reinforce professionalism, formality and seriousness of the mission. It implies that the dollar deal is done and they are agreed upon the plan. The size of participants' heads is bigger than body and Chamberlin looks taller than Aziz. Her size draws our attention to the power and significance. Aziz is bent and seems obedient and compliant.

Their big heads and tiny bodies' connote egoism, cockiness and most importantly their foolishness. This also signifies that they are self-assertive; pursuing their own interests relentlessly and negligent about the condition of the economy that is breathing last sigh. Figure 3 contains one human figure President Musharraf in a state of being covered with different currencies. A cloud of mercy is producing wads of money in the form of numerous currencies that has covered the whole body of President Musharraf. The small stature of Musharraf symbolizes his meanness and his wide spread big nose suggests his greediness for money as wide big nose carries associations with money. The face of the actor indicates mental processes of satisfaction and gratification. This means that he is depicted in such a way that brings a sense of fulfilment of his needs or wants. Musharraf is drowned in the heaps of money and feeling relaxed, uplifted and honoured. Musharraf's body is not visible except his face which suggests how badly he was captured by the powerful partners to their game.

Whereas, figure 2 presents President Musharraf half lying on the floor and seems dejected and broken. He looks down and losing. The reason for his dejection and disappointment is portrayed through the empty shown 'begging bowl' written on it 'major economic relief from Bush with love'. This is used to symbolize the US small calibrated doses of comfort not satisfying Musharaf who made a 


\section{Review of Economics and Development Studies, Vol. 6 (2) 2020, 531-543}

strong bid for writing off debts. Musharraf's closed eyes, folded arms; slouched shoulders and lazy posture all show his pain, grief and mental distress. Figure 4 represents three participants; the doctor, the patient and the attendant. The man in walking position is the US Secretary of State Colin Powell, in lying position is the person represents Pakistan's economy and the third is the attendant serving the ill. The doctor is leaving the place carrying bag in one hand and waving left hand to say good bye to the patient. The person who lies on the bed seems injured and his whole body is covered with strip of fabric used to heel up the wounds. That shows his critical condition. He looks critical and crying while holding bouquet in his hand. As the injured person represents Pakistan's economy, his worst condition symbolizes the worst condition of Pakistan's economy.

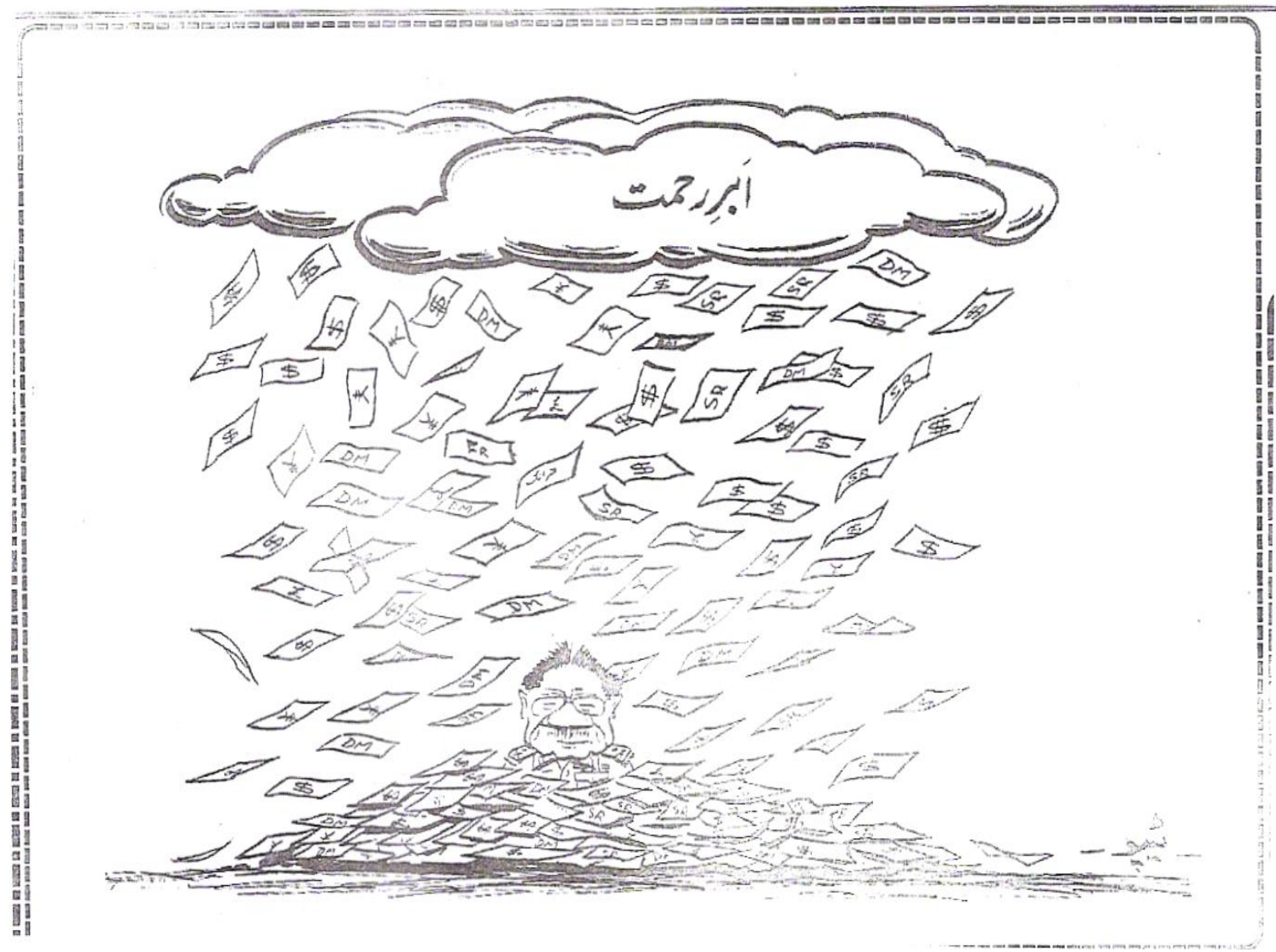

Figure 2 taken from daily 'Ausaf' Dated: 5-10-2001

\subsubsection{Settings}

Figure 1 represents no settings as the participants stand against the plain background but the use of white and dark shadows is meaning potential. The disjointed line at the bottom that provides space to the participants to put their feet is highly symbolic. The participants are shown in the same frame but the gap actually separates them and indicates that they are different and the strength of the connection between them is poor. According to Machin (2007) where the elements are separated by empty space it indicates the distance between them. This is ideological and suggests that the gap is bridged by being together to form a single unit. Though, Aziz seems more in trouble striving hard to cement the relation. The dark shadows at the top of both sides connote gloom and worry but the bright white that surrounds the participants connotes hope and wish being expected out of the activity.

Similarly, in figure 3, the dark and white shadows are employed. The white bright light that encircled the bowl shows hope and optimism whereas the dark shadows surrounding the white bright 


\section{Review of Economics and Development Studies, Vol. 6 (2) 2020, 531-543}

show despair, pessimism, defeatism and hopelessness. Musharraf's face is more in dark and less in light. In this cartoon, Musharraf, is seen to be dreaming of the economic relief that would be given by Bush, he is sleeping while a little portion of his tongue is out to show his desire for getting the aid from America.

This connotes the dark mood of him and communicates his despondency. The whole setting brings an atmosphere of despondency and a gloom fell over Musharraf. Important in both of these figures is the use of dark and white lightening, which suggests optimism as well as pessimism.

In figure 2, settings include people and objects set against plain background. The setting that is denoted shows a cloud and currencies. What is connoted is the rain of currencies. Here, the salience is given to the cloud producing abundant money that fades the participant into the loads of money. The cloud is very important here for its association. It serves to foreground the ecstasy of the participant fully covered with numerous falling currencies. In terms of semiotic choices, the participant's concern is represented through rain which is the sign of blessings. So, in the image the rain of money is the greatest blessing for him. The empty setting evokes the idea depicted more through the actor and objects. The abstraction reveals that ideological work is being done. As Fairclough (2003) explains, whenever abstractions replace actual places, actions and persons, it indicates about the ideological work.

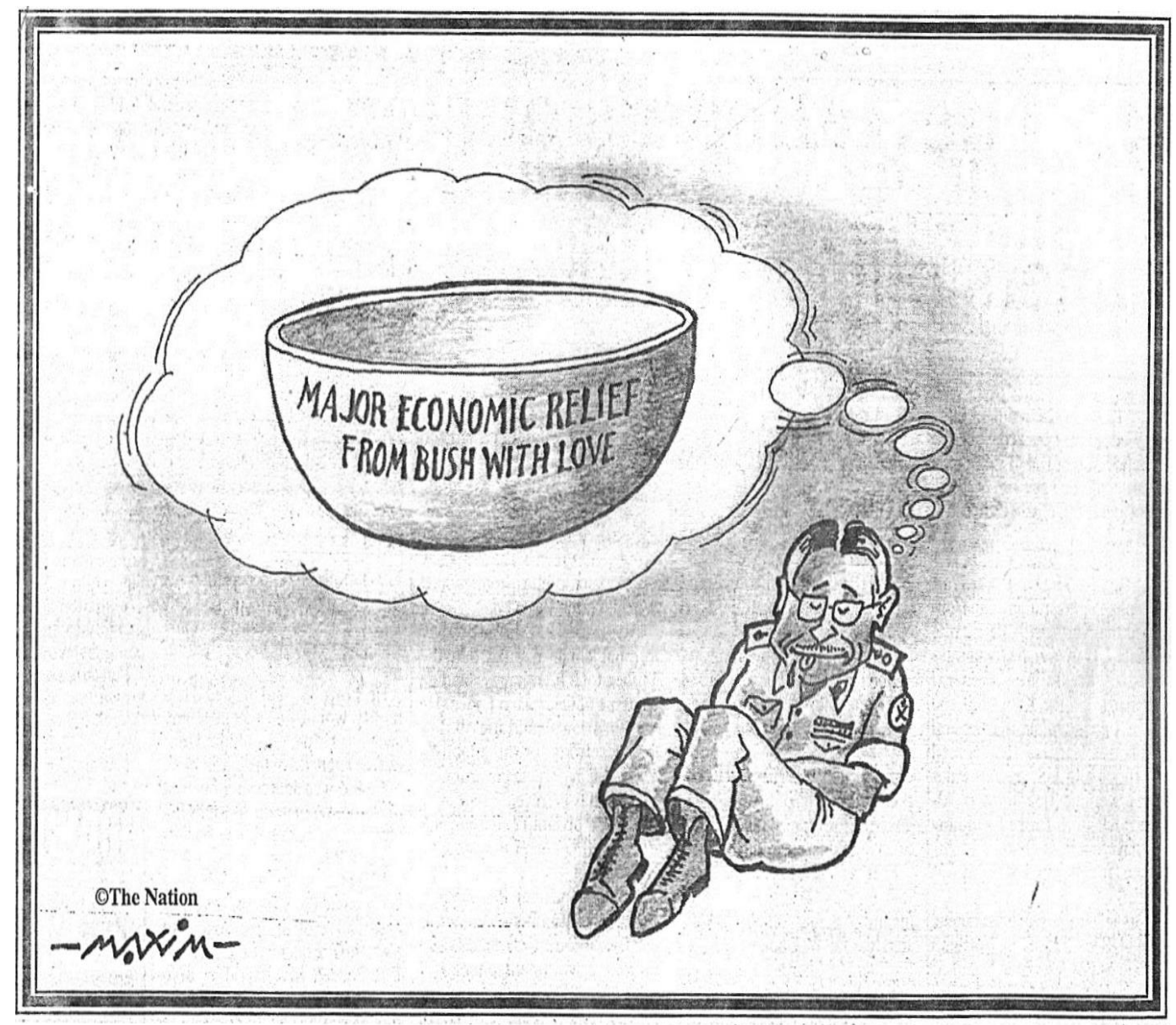

Figure 3 taken from daily 'The Nation' Dated: 16-11-2001

Figure 4 represents settings only in terms of abstracted space. Apart from the props which indicate a type of person and a kind of professional activity, there is no setting. There is just a blank space, whiteness. Only props allude to the concept. It could be a room in the hospital. The iconography 


\section{Review of Economics and Development Studies, Vol. 6 (2) 2020, 531-543}

that connotes hospital is the stethoscope around the neck of the man at the front of the cartoon and also important is the person wrapped in bandages lying on the bed to the right of the cartoon. This is to signify that the medical treatment is being given to the injured person. The setting is plain and symbolizes the treatment of sick economy of Pakistan by the American doctor. Apart from the props, which indicate a type of person and a kind of professional activity, there is no setting to speak off.

\subsubsection{Poses}

Machin (2007, p. 31) says 'poses are a semiotic resource that can be used for their meaning potential'. In figure 1 we find participants in standing posture and their poses suggest some activity. Chamberline stands straight and relaxed but at the same time emphasizing power, authority and control. In contrast, Aziz's bending and leaning posture connotes submissiveness and subjugation to the authority. The curve minimizes his physical size to remain inferior in status to the woman. He stoops down to present the child to the authority for drops. Here, his posture lowers his status relationship. The image invokes the stereotyped role of Pakistan and the US officials in the cartoons. Both participants wear a big smile that suggests outward pleasure and hides the inner scorn. Chamberline also stands with arms bit open, taking up space but is not looking at the viewers.

Figure 2 contains a very striking pose. The participant has drowned in the heaps of money. He might be standing as his lower body completely covered with money. But the posture connotes no physical regimentation or control. It is a lose pose and suggests he is at 'their' mercy. This dull and sluggish posture connotes his insensibility, poor vision and lack of physical power. The closed eyes' look makes him appear defensive and idiot. Here, the connotation is one of 'wariness' and 'cautiousness' rather than happiness or cheerfulness.

We see Musharraf in half lying posture on the floor in figure 3. His arms are folded, legs are bent and eyes are closed. Here, with folding arms and bent knees he takes less space and his facial expressions denote some misery. These actually reflect his defeatism, failure and desperation. He is lying but doesn't seem at ease. The posture connotes discomfort, misery, angst and a sense of utter desolation. Dismayed and upset Musharraf doesn't want to face the viewers so he closes his eyes and not encouraging them for any relationship. We see, the representation of the participant in particular pose is the connotators of particular identities. The typical negative portrayal of Musharraf shapes the readers' thinking and behaviour towards him.

In figure 4, the participant at front is shown in walking position leaving the room and at the same time waving hand to say good bye to other participants. The pose suggests that some activity has been done as the pose of other participant seems reactional. The bodily response of the injured person connotes pain, wonder and amazement. The walking person seems confident and authoritative. He is looking backward and his facial expression connotes slight frown that is unwelcoming and maintains a social distance. In the cartoon, we find Powell appearing to be quite serious and unemotional. He expresses no feelings and is represented as being cold, formal and indifferent to the situation. Whereas, the injured person's open mouth suggests his surprise as well as seems screaming on receiving the treatment from the doctor.

The attendant plays a role of a sympathizer as he seems down looking at the crying one. The poses of the injured person connote acute pain and disappointment. This image is depicted in the cartoon to represent Pakistan's economy as it is declining due to heavy foreign loans. So, the poses and the facial expression of the person lack sobriety and grace. His pose encourages the viewers to see him as threatened and struggling. The image connotes the values of the looser and the needy. The physical 
Review of Economics and Development Studies, Vol. 6 (2) 2020, 531-543

control and discipline in the case of doctor metaphorically connotes power and control whereas, the loose and scared poses of the patient signify the lack of integrity, honour and self- respect.

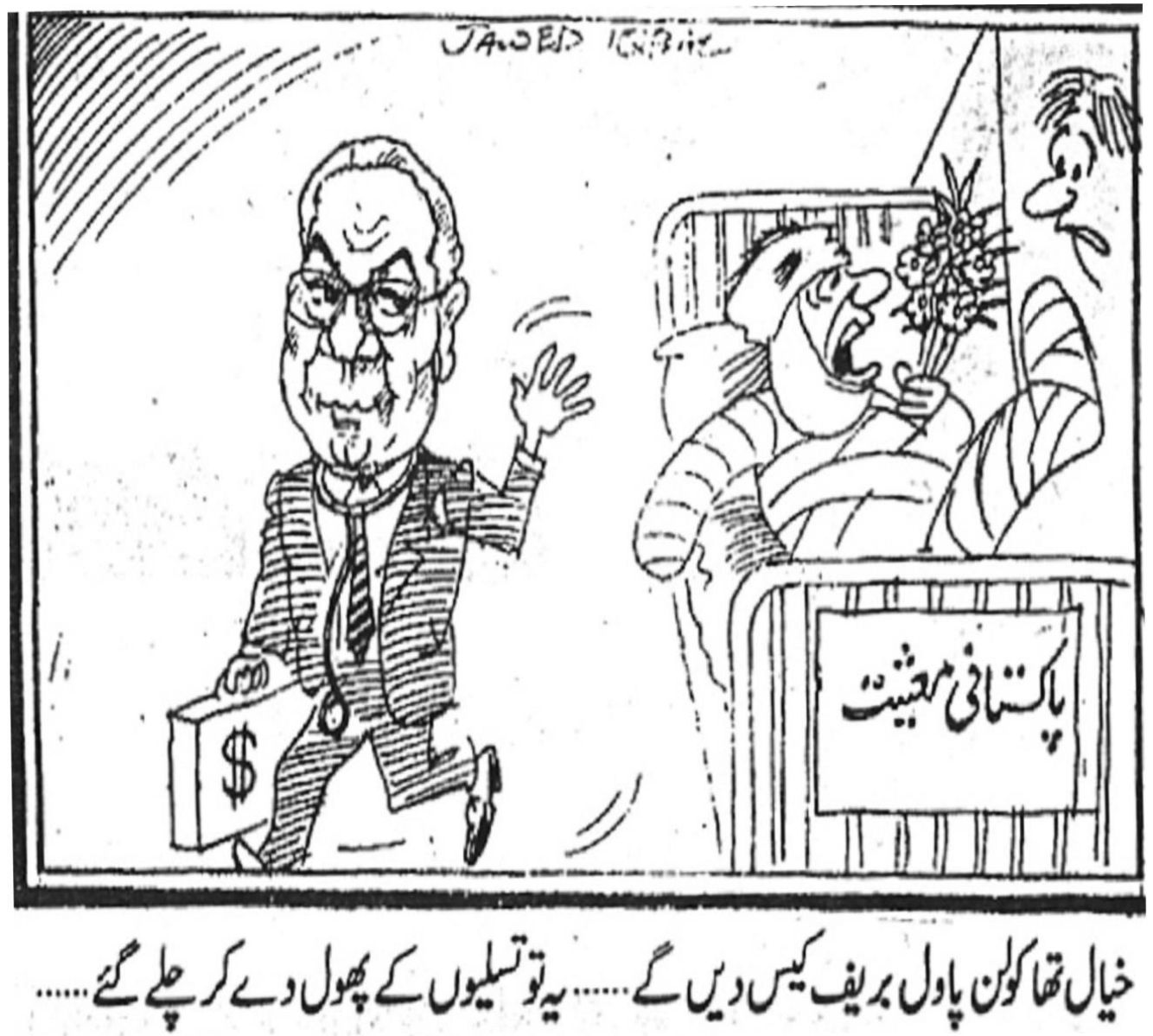

Figure 4 taken from daily 'Jang' Dated: 18-10-2001

\subsubsection{Objects}

Objects are very important carrier of connotation. In the cartoon, objects such as the dropper, bottle, bowl, currencies, bed, stethoscope, bouquet and the bag can be seen as the connotors of particular meanings. Machin (2004, p. 322) says:

"Props are used to connote not only the setting but identities of the actors and the nature of the activities".

Figure 1 represents a woman holding a bottle in the left hand and a dropper in the right hand, whose clothing is formal and wearing high heels. It is important to note that the woman is holding a particular kind of bottle as the dollar sign is printed on it. This suggests that she is dropping the US dollar juice into the flimsy child's mouth for energy and strength. It has particular connotation the way it combines with other meanings in the cartoon. Here, it connotes that what a handsome sum of money is being paid to Pakistan on sullying national honour and by behaving in too supine a manner. Are few drops of aid sufficient to pay cost of our battered pride as a nation? Theses few drops of aid therefore can't help Pakistan's dying economy, there is the need to provide huge support to the economy of Pakistan so that it could attain some stability.

In figure 2, the numerous currencies and cloud are shown as the objects. These connote prosperity, mercy and blessings. In order to understand the associative meanings of the objects, it is 


\section{Review of Economics and Development Studies, Vol. 6 (2) 2020, 531-543}

important to see how they combine with other elements in the cartoon. The props foreground Musharraf's vision of abundant economic aid coming from the top most powerful countries to ease Pakistan's economy. It suggests Musharraf's state of trance and ecstasy. He lives in fancy and conceptualizing all this happening. His eyes are closed watching the daydream.

The cloud is the sign of an impeding heavy downpour. The heavy rain of money implies the chaos that has resulted in the massive loss of national interest. Figure 3 contains the object 'bowl' and the bubbles surrounding it. The printed line on the bowl is making it meaning potential and connotes that it is a special bowl. The white bubbles surrounding the bowl are linking it with the participant. Infact, the whiteness encircling the bowl represents the wretchedness of Musharraf who seems deplorably distressing after seeing the gift from Bush. This indicates that the little amount of relief from Bush has shattered Musharraf's hopes and aspirations for the huge economic relief or aid. Finally, in figure 4, one could find objects like, a stethoscope, a bag, a bouquet and a bed. These are associated with hospital settings. The stethoscope around the neck of the man at front suggests him doctor though he is not wearing a white coat. The man becomes a doctor because of the attribute stethoscope. Take off the stethoscope, he could become a businessman as the clothes too suggest. He carries a particular kind of bag that connotes money not medicine. If the meanings of these props are combined with others in the cartoon, then, a particular context develops. The bed, the bouquet and the man wrapped in strips together connote a particular kind of person and a particular kind of activity. The pose of the man on the bed suggests extreme pain and he cries with wonder looking questionably at the attendant. As he represents Pakistan's economy, so, the props hereby suggest that the dying economy of Pakistan needs medication in the form of the US dollar for the survival. But the US doctor who is holding a dollar bag gives the bouquet to the injured person and leaves. The wounded person gets hurt by this and cries with pain pain as he was expecting some kind of treatment or the medicine but was provided with the bouquet just like a lollipop is given to the children to divert their attention.

\section{5- Linguistic Analysis}

Figure 1 only contains visuals and there is no text. In figure 2, the Urdu noun phrase 'abre-erehmet is used. The cloud is labeled as "abre-e-rehmet” means the 'cloud of mercy'. It is important to note that meaning is not a monolithic construct; it is a multidimensional and having meaning in context. The noun phrase "abre-e-rahmet" is used for raining that Allah has blessed us with His mercy. Here, the cloudburst of dominant currencies on Musharraf is meaning potential. It signifies that President Musharraf is being blessed by the superpowers' heavy downpour of currencies.

It is certainly not told why he is receiving this. But the suppression of the information signals buried ideologies and broader discourses. There is the suppression of the interests, motives and reasons behind the rain. Meanings are hidden behind the rain. The lexis is used in the cartoon to symbolize those events happened after 9/11. Here, irony is used though not shown in the linguistic form directly. To some extent, irony belongs to the realm of contextual meaning rather than the formal meaning that we find in the lexis. As here it alludes to Musharraf's unstinted cooperation on global war against terrorism. This blessing is the result of his divine favour. It reflects the compassionate treatment from the superpowers to acknowledge his services. Musharraf is receiving reward in the form of economic relief. The visual and written discourse is indeed an ideological loaded discourse as Fairclough (1995) underlines the fact that the ideological nature of media language entails specific constructions of the world and the social identities.

In figure 3, the linguistic caption 'major economic relief from Bush with love' is used. The use of the adjective major implies that Pakistan has already been awarded with the economic relief but this is 


\section{Review of Economics and Development Studies, Vol. 6 (2) 2020, 531-543}

greater in quantity. Pakistan is getting this relief on its services during the war against terror. The visual representation suggests that it is a begging bowl and Musharraf is disappointed seeing the amount of relief issued by Bush. It is an ideological loaded text. As Van Dijk (1993, p. 250) says that language 'constitutes a particular way of talking about and understanding the world (or an aspect of the world)'. In figure 4, the linguistic text is 'khayal tha Colin Powell briefcase dein gein ye to tasaleoon $\mathrm{k}$ phool de ker chaly gae' means 'we hoped for major economic relief but got words of sympathy only'. The phrase tasaleon $\mathrm{k}$ phool (words of sympathy) connotes that Pakistan was expecting a huge economic relief but got nothing other than the verbal sympathy so it was just opposite to what Pakistan was expecting.

The use of metaphor 'briefcase' for money (economic relief) indicates Pakistan's hopes for the financial relief. The use of this linguistic device makes the language attractive as well as the process of ideology investment is facilitated. In this line, money is described in terms of the briefcase. No actual money is shown but the metaphor brings the connotations of the economic relief. Fairclough (1995) points out that metaphors have hidden ideologies due to the way that they can conceal and shape understandings while at the same time giving the impression that they reveal them.

\section{Conclusion}

The analysis of the political cartoons on the economic issue reveals the underlying discourses and buried ideologies. The researcher examined how cartoons represent particular social practices in order to understand the issue in the given context. When we look how the actors are represented visually as doing we find that there is a much more negative evaluation of the actors. The choice of attributes, poses and actions to represent Musharraf in the cartoons suggests a greater indignation against him and disseminates a specific representation of the event. All other factors and aspects leading to the crisis are put out of sight. The cartoonists have invested considerable semiotic resources in promotion of the issue of economic crisis in Pakistan after coalition with America and allies to combat war on terror. Depiction selects and links elements to specific actions and provides moral evaluation, the use of value-laden concept such as begging, beseeching, requesting and pleading trigger moral concepts and then evaluates social practice and actor in that context. The visual and linguistic representations being the powerful ideological tools manipulate readers' perception and interpretation of people and events. Musharraf's identity as the beggar and America's as the benefactor is consolidated by foregrounding the images represent the former as the pauper and later as the donor. This establishes the belief that the cartoons possess the power to make a choice over whose image (negative, positive) is foregrounded or backgrounded.

The representations effectively reinforce the images of Pakistan fighting war for the economic benefits being the crony of America. The recontextualisation of the event manifests the ideological construction of identity and role of two states, Pakistan as the compliant and the US as the master. The economic game is being played between the social players whose representations referring complexity of the situation and indicates who betrays, creates, controls and leaves. The evaluation of the events works with desirability and undesirability of the producer and also in terms of usefulness and in line with public interest.

\section{References}

Fairclough, N. (1995). Critical Discourse Analysis: The Critical Study of Language. London: Longman. Fairclough, N. (2003). Analysing Discourse: Textual Analysis for Social Research. London: Routledge. Machin, D. (2004). Branding the World's Visual Language: The Increasing Global Importance of Image Banks in Corporate Media. Visual Communication 3: 316. 
Machin, D. (2007). Introduction to Multimodal Analysis. Bloombury: London

Machin, D. Mayr, A. (2012). How to do Critical Discourse Analysis. London: Sage.

Van Dijk, A. T. (2001). Critical Discourse Analysis in The Handbook of Discourse Analysis. (eds) Deborah Schiffrin, Deborah Tannen, and Heidi E. Hamilton. Massachusetts Blackwell Publishers Ltd.

Van Dijk, T. A. (1993). Principles of Critical Discourse Analysis. Discourse and Society, 4 (2), 249-283.

Van, Leeuwen, T. (1996). The Representation of Social Actors in Discourse. In C.R. Caldas-Coulthard \& M. Coulthard (Eds.) Text and Practice: Reading in Critical Discourse Analysis. Pp 32-70. London: Routledge.

Van, Leeuwen. T. (2008). Discourse and Practice. New Tools For Critical Discourse Analysis. Oxford University Press.

Weiss, G. \& Wodak, R. (2003). Critical Discourse Analysis: Theory and Interdisciplinarity. London: palgrave Macmillan. 